Volume 2 Issue 2, July-Desember 2021: pp.75-86.

Faculty of Law, Universitas Lampung, Bandar Lampung, Indonesia. http://jurnal.fh.unila.ac.id/index.php/ip

P-ISSN: 2723-2638 E-ISSN: 2745-9314

\title{
Verbalisan Witness Position as Evidence of a Criminal Case
}

\author{
M. Kemal Pasha Zahrie \\ Central Lampung District Prosecutor's Office, Indonesia \\ kemalpasha22@yahoo.com
}

Submitted: Jan 12, 2021; Reviewed: Jan 20, 2021; Accepted: Apr 5, 2021

\section{Article's Information}

keywords:

Evidence; Verbalisan; Witness.

DOI :

https://doi.org/10.25041/ip.v2i2.2213
The presence of Constitutional Court Decision Number 65/PUUVIII/2010 expands the meaning of witnesses in Article 1 point 26 of the KUHAP, resulting in the emergence of various interpretations in criminal justice practice concerning the position of verbal witness testimony as evidence. Juridically, the decision creates problems considering that the Criminal Procedure Code or Kitab Undang-Undang Hukum Acara Pidana (KUHAP) does not recognize verbal witnesses' testimony as evidence. This study examined the position and the strength of verbal witnesses' testimony as evidence in criminal proceedings. After gathering all the data using normative and empirical juridical research, this paper concludes that the testimony of verbal witnesses is grouped in the evidence of guidance in Article 188 Paragraph (1) of the KUHAP because the testimony of verbal witnesses is not primary evidence. After all, its existence is contingent on the judge's willingness to employ it. The strength of proof of testimony of verbal witnesses is that they must satisfy the elements of Article 188 paragraph (1) of the KUHAP, namely the information referred to in the form of events or circumstances concerning a criminal act, as well as conformity with other evidence, as required by Article 188 paragraph (2) of the KUHAP.

\section{A. Introduction}

The submission of a criminal case examination to trial by the public prosecutor has a juridical consequence that the public prosecutor must prove all allegations addressed to the defendant in his indictment. In contrast, the defendant is not required to prove every charge levelled against him as regulated in Article 66 of the Criminal Procedure Code or Kitab Undang- 
Undang Hukum Acara Pidana (KUHAP) of Indonesia. ${ }^{1}$ Witnesses and defendants must be regarded as persons with unique qualities and needs. ${ }^{2}$ Therefore, criminal law and procedure have mechanisms to ensure that individual defendants are arrested, prosecuted, convicted, and sentenced in proportion to their desert. ${ }^{3}$

The essence of the examination of a criminal case through a judicial process is carried out based on the objective of seeking the material truth of the occurrence of a criminal event, thus to determine whether the defendant is worthy and deserves to be sentenced to a conviction or sanction for the accused must be based on the result of evidence, which is limitedly determined in article 183 of KUHAP, explains that at least two valid pieces of evidence, as stipulated in Article 184 Paragraph (1), along with the judge's conviction about the truth of the criminal act and the defendant guilty of committing the crime. ${ }^{4}$

Observing the provisions of Article 184 Paragraph (1) of the KUHAP, it is known that it does not contain testimony of verbal witnesses as valid evidence. However, in criminal justice practice, verbal witnesses are often presented and used by the public prosecutor as a means of proof. The prosecutor can see this based on field data that the author obtained from the Central Lampung District Prosecutor's Office, including the following:

Table 1: Proof of criminal cases using verbal witnesses at the Gunung Sugih District Court from 2017 to 2019

\begin{tabular}{|c|l|l|c|c|}
\hline No. & \multicolumn{1}{|c|}{ Types of Crime } & \multicolumn{1}{|c|}{ Case Number } & Year & $\begin{array}{c}\text { Number of Submitted } \\
\text { Verbalisan Witnesses }\end{array}$ \\
\hline 1. & Fencing & 43/Pid.B/2019/PN.Gns & 2019 & 1 \\
\hline 2. & Fraud & 84/Pid.B/2019/PN.Gns & 2019 & 2 \\
\hline 3. & Embezzlement & 178/Pid.B/2019/PN.Gns & 2019 & 2 \\
\hline 4. & Extortion & 420/Pid.B/2019/PN.Gns & 2019 & 1 \\
\hline 5. & Narcotic Abuse & 444/Pid.Sus/2019/PN.Gns & 2019 & 1 \\
\hline 7. & Fraud & 256/Pid.B/2018/PN.Gns & 2018 & 1 \\
\hline 8. & Environmental Destruction & 166/Pid.B/L.H/2018/PN.Gns & 2018 & 1 \\
\hline 9. & Health Practices & 106/Pid.Sus/2018/PN.Gns & 2018 & 1 \\
\hline 10. & $\begin{array}{l}\text { Fornication towards } \\
\text { Children }\end{array}$ & 235/Pid.Sus/2017/PN.Gns & 2017 & 1 \\
\hline
\end{tabular}

Source: Database of criminal cases at the Central Lampung District Attorney in 2017-2019

Based on the data presented above, it is clear that the use of verbal witnesses by the public prosecutor in the process of proving criminal cases, particularly at the Gunung Sugih District Court, has increased from 2017 to 2019. Although verbal witnesses can be used as evidence in practice, their legal status is not defined in KUHAP Article 184 paragraph (1).

A verbal witness is an investigator who later becomes a witness in a criminal case because the defendant states that the investigation report has been made under pressure or coercion. In other words, the defendant denies the truth of the examination report or revokes

\footnotetext{
1 Henny Elvandari, Burham Pranawa, and Joko Mardiyanto, "Kedudukan Saksi Verbalisan Dalam Proses Pemeriksaan Di Persidangan," Jurnal Bedah Hukum 4, no. 2 (October 31, 2020): 10-19, https://www.ejournal.uby.ac.id/index.php/jbh/article/view/451.

${ }^{2}$ Laura Hoyano, "Reforming the Adversarial Trial for Vulnerable Witnesses and Defendants," Criminal Law Review 2, no. February 2015 (2015): 107-29.

${ }^{3}$ Richard A. Bierschbach and Stephanos. Bibas, "Rationing Criminal Justice," Michigan Law Review 116, no. 2 (2017): 187, https://repository.law.umich.edu/mlr/voll16/iss2/1.

${ }^{4}$ Muhammad Erham Amin and Putri Damayanti, "Kekuatan Pembuktian Penyidik Kepolisian Selaku Saksi Dalam Persidangan Tindak Pidana Narkotika," Badamai Law Journal 4, no. 2 (September 25, 2019): 256, https://doi.org/10.32801/damai.v4i2.9236.
} 
the information in the examination report prepared by the investigator concerned. ${ }^{5}$ In this regard, it is known that the presence of verbal witnesses at trial is situational based on the occurrence of events or circumstances when the information is withdrawn in the Investigation Report or Berita Acara Pemeriksaan (BAP) by the defendant. The presence of verbal witnesses is also limited to providing information relevant to the defendant's withdrawal of the BAP statement. Thus, the author understands that verbal witnesses are not the primary evidence to prove a criminal case in court. ${ }^{6}$

Since Constitutional Court Decision Number 65/PUU-VIII/2010, in which the verdict states that Article 1 number 26 and number 27; Article 65; Article 116 Paragraph (3) and Paragraph (4); and Article 184 Paragraph (1) letter a of Law Number 8 of 1981 concerning Criminal Procedure Law (State Gazette of the Republic of Indonesia Year 1981 Number 76 and Supplement to State Gazette of the Republic of Indonesia Number 3209) has contravened the 1945 Constitution of the Republic of Indonesia and has no binding legal force as long as the meaning of the witness in Article 1 number 26 and number 27; Article 65; Article 116 Paragraph (3) and Paragraph (4); Article 184 paragraph (1) letter a of Law Number 8 of 1981 concerning Criminal Procedure Law (State Gazette of the Republic of Indonesia of 1981 Number 76 and Supplement to the State Gazette of the Republic of Indonesia Number 3209) does not include "a person who can provide information in the context of an investigation, prosecution, and trial of a criminal act which he does not always hear himself, he sees and experiences himself" juridically has an impact on a paradigm shift in understanding the existence of witnesses in the judicial process criminal, from what was initially referred to as "a person who sees, hears and experiences a criminal act for himself", now has changed to "a person who does not always see, hear and experience for himself", witnesses with their verbal statements also need to be heard in the trial process.

The essence of the Constitutional Court Decision Number 65/PUU-VIII/2010 is aimed at providing balance in the process of proof in criminal justice and to fulfilling the rights of the defendant in terms of presenting witnesses to lighten up the trial that collides with the classification of witnesses as regulated in Article 1 numbers 26 and 27 KUHAP. However, expanding the definition of witnesses opens up more opportunities for public prosecutors to always present verbal witnesses in court if some witnesses or defendants withdraw their testimony in the BAP. This practice underlines the need to research the position of verbal witness testimony as a means of proof in a criminal case. This study focuses on the problem of the position of verbal sanction information as a tool in criminal proceedings and the strength of proof of testimony of verbal witnesses in criminal proceedings, which are studied using normative-empirical legal research methods.

\section{B. Discussion}

\section{Statement of Verbalisan Witnesses as Criminal Case Evidence}

A legal review of verbal witnesses in criminal cases will attempt to explain the existence of variables and a close correlation between theories about crime and punishment on the one hand and criminal judges' policies on the other. The two theories are a unified whole and inseparable within the framework of the criminal justice system to find material truths that can shape the judge's conviction to take a decision that is deemed fair based on law and truth.

\footnotetext{
${ }^{5}$ Salut Murniasih, "Pembuktian Berdasar Keterangan Saksi Verbalisan Akibat Pencabutan Keterangan Terdakwa Di Persidangan Dalam Perkara Persetubuhan Terhadap Anak," Jurnal Verstek 7, no. 2 (2019): 192-99, https://jurnal.uns.ac.id/verstek/article/view/34306.

${ }^{6}$ Hana Krisnamurti, “Kedudukan Saksi Anak Dalam Pembuktian Perkara Pidana," Wacana Paramarta: Jurnal Ilmu Hukum 15, no. 2 (2016): 1-11, http://paramarta.web.id/index.php/paramarta/article/view/28.
} 
Law enforcement is a powerful system, structural system, and cultural system. ${ }^{7}$ One of which is carried out through the evidentiary stage, which is crucial in examining criminal cases in court to enforce the law on the occurrence of criminal acts in society. Proof has 2 (two) functions, namely, for the public prosecutor. Before referring a case to prosecutors, police officers must interview victims and suspects and gather sufficient evidence. ${ }^{8}$ It functions as an effort to prove the truth of the criminal incident described in the indictment letter so that a judge can sentence the defendant to fulfil the minimum requirements of two valid evidence tools. Second, for the defendant to function as an attempt to deny the public prosecutor's indictment of the criminal act, he is accused of or attempting to ask the judge for leniency if the defendant pleads guilty to committing a criminal act as charged by the public prosecutor. ${ }^{9}$

Evidence and proving in the criminal procedure are the tools for achieving criminal procedure goals. ${ }^{10}$ Communication plays a key role in a witness's ability to give evidence and participate in the court process. ${ }^{11}$ Evidence has a role as anything used to prove the truth of an event in court. ${ }^{12}$ Every piece of evidence presented at trial must at least meet the following requirements:

a. Evidence must be relevant or related.

b. Evidence must be reliable, meaning that the evidence is reliable so that to strengthen the evidence, it must be supported by other evidence.

c. Evidence must not be based on improper suspicion. It must be objective in providing information about a fact. ${ }^{13}$

The evidentiary process's result will lead to the overthrow of the judge's decision. Thus the trial facts obtained during the evidentiary process will significantly determine the judge's decision. The facts referred to are the conclusions of witness testimony, expert testimony, letters, instructions, and defendant statements that will be related to the time and place of the crime, how the crime was committed, the background of the crime, the consequences of the act, evidence, and other matters relating to the crime charged against the defendant. Furthermore, one of the Central Lampung District Prosecutor's in an interview explains that what is meant by the strength of evidence is the extent to which the value of each evidence tool can be used to prove the truth of a criminal event and prove that the defendant is the perpetrator. ${ }^{14}$ In juridical terms, the value of the strength of evidence as determined by Article 184 Paragraph (1) of the KUHAP in the form of witness testimony, expert testimony, letters, instructions, and statements of the defendant is the same; none of this evidence is more

\footnotetext{
7 Erna Dewi, "Rekonstruksi Budaya Hakim Pada Penegakan Hukum Pidana Dalam Konteks Siskumnas/Bangkumnas," Jurnal Kompilasi $1 \quad$ (October $28, \quad 2014$ ): 106-378, https://www.neliti.com/id/publications/106378/.

${ }^{8}$ Bradley A. Campbell, Tasha A. Menaker, and William R. King, "The Determination of Victim Credibility by Adult and Juvenile Sexual Assault Investigators,” Journal of Criminal Justice 43, no. 1 (2015): 29-39, https://doi.org/10.1016/j.jcrimjus.2014.12.001.

9 Tiovany A. Kawengian, "Peranan Keterangan Saksi Sebagai Salah Satu Alat Bukti Dalam Proses Pidana Menurut KUHAP,” Lex Privatum 4, no. 4 (April 27, 2016): 30-37,

https://ejournal.unsrat.ac.id/index.php/lexprivatum/article/view/11990.

10 Roman V. Kostenko and Artem Rudin, "Notion And Meaning Of Evidence Verification In Criminal Procedure," Journal of Advanced Research in Law and Economics 9, no. 3 (2018): 1011.

11 Joanne Morisson, Jill Bradshaw, and Glynis Murphy, "Reported Communication Challenges for Adult Witnesses with Intellectual Disabilities Giving Evidence in Court," The International Journal of Evidence \& Proof 25, no. 4 (2021): 243-63, https://doi.org/10.1177/13657127211031040.

${ }^{12}$ I. Rusyadi, "Kekuatan Alat Bukti Dalam Persidangan Perkara Pidana," Jurnal Hukum PRIORIS 5, no. 2

(February 13, 2016): 128-34, https://trijurnal.lemlit.trisakti.ac.id/prioris/article/view/558.

${ }^{13}$ Eddy O.S Hiraiej, Teori Dan Hukum Pembuktian (Jakarta: Erlangga, 2012): 13.

${ }^{14}$ Interview with the Central Lampung District Attorney's Office on May 5, 2020.
} 
dominant than one another. Among them are dependent because these pieces of evidence must support each other and relate to one another. ${ }^{15}$

The defendant often retracted the BAP information for various reasons in connection with the evidentiary process at trial. The Mountain District Court Judge viewed the withdrawal of a defendant's statement as an act of retracting his testimony, which was initially stated in the BAP when an investigator is being examined as a suspect. ${ }^{16}$ For this matter, the judge does not automatically grant the defendant's request but must analyse the basis or reason for the request to withdraw his testimony. In addition, to put this to the test, the judge frequently requests that the public prosecutor present an investigator who examines at the level of investigation to provide information at trial, which is commonly referred to as verbal witnessing in practice. When an investigator is being investigated as a suspect, withdrawing a defendant's statement is an act of retracting his testimony, as stated in the BAP.

The law does not limit the defendant's right to retract information provided during the investigation, as long as the revocation is carried out during the trial examination and has a justifiable and logical reason. ${ }^{17}$ The defendant's withdrawal of the BAP statement is extremely damaging to the public prosecutor because it has implications for the indictment's weakness, which has been prepared and submitted to the court as a basis for trying the defendant. As a result, when the defendant withdraws his statement in the BAP, the description of the criminal incident in the indictment becomes inconsistent with the facts of the trial.

An indictment is a letter or deed containing the formulation of a criminal offense charged against a defendant, which is concluded and withdrawn from the results of an investigative examination and is the basis and basis for the judge in the examination before a court session. ${ }^{18}$ Thus the withdrawal of the statement of the Investigation Report (BAP) of the defendant's investigation is the main reason for the presence of verbal witnesses at the court whose function is to prove the truth of the defendant's reasons for withdrawing the statements of the BAP. The expansion of the understanding of witnesses in the Criminal Procedure Code (KUHAP) based on the Constitutional Court decision Number 65 / PUU-VIII / 2010 has brought significant changes to the determination of evidence for witness testimony. Based on the decision of the Constitutional Court, the witness statement is no longer determined in a limited manner as the testimony that the witness has personally, the witness sees and the witness experiences himself, but has been interpreted more broadly as information given by someone regarding a criminal act that is not always heard by himself, see it yourself and experience it yourself. However, this decision has not placed verbal witnesses' position so that there are still various interpretations of the verbal witnesses in question in criminal justice practice.

The use of verbal witnesses in criminal justice practice has become a habit from time to time. Before the Constitutional Court's decision, verbal witnesses can be placed as evidence by the judge if the information referred to is compatible with other evidence because the substance of the verbal witnesses has the character of explaining coherently about the implementation of the investigation process so that the information is valuable as information about the occurrence of a criminal event and who the perpetrator. However, as of the Constitutional Court's decision, verbal witnesses' statements can be interpreted as evidence of

\footnotetext{
${ }^{15}$ Muhammad Iftar Aryaputra et al., "Peranan Keterangan Saksi Sebagai Salah Satu Alat Bukti Dalam Proses Pidana Menurut KUHAP," Jurnal Dinamika Sosial Budaya 20, no. 2 (January 21, 2019): 91, https://doi.org/10.26623/jdsb.v20i2.1241.

${ }^{16}$ Interview with the Judge of the Gunung Sugih District Court on May 8, 2020.

17 Andriyanto Andriyanto, "Pencabutan BAP Oleh Terdakwa Di Muka Persidangan Dalam Sistem Peradilan Pidana," LEX CRIMEN 7, no. $2 \quad$ (May $22, \quad$ 2018): $105-12$, https://ejournal.unsrat.ac.id/index.php/lexcrimen/article/view/19600.

${ }^{18}$ Ganda Yusaf A., "Kewajiban Menyampaikan Surat Dakwaan Oleh Penuntut Umum Kepada Terdakwa Atau Penasihat Hukumnya,” Jurist-Diction 2, no. 3 (July 11, 2019): 891, https://doi.org/10.20473/jd.v2i3.14361.
} 
witness testimony because the Constitutional Court decision has expanded the classification of witnesses regulated in the KUHAP. ${ }^{19}$

Based on the research conducted, it is known that there are 2 (two) points of view regarding the position of verbal witness testimony in proving a criminal case at trial, namely as a means of evidence and as evidence of witness testimony. On this, it can be analyzed as follows:

\section{a. In connection with the placement of the testimony of the verbal witness as evidence of guidance.}

Observing the provisions of Article 188 Paragraph (1) of the KUHAP, which defines an indication is an act, event, or situation which because of its compatibility, whether between one another or with the criminal act itself, indicates that a criminal act has occurred and who the perpetrator is. Therefore, it can be analyzed that this provision has relevance if it is related to the substance of the testimony of a verbal witness, which is oriented to matters related to the revocation of the statement of the defendant in the Investigation Investigation Report so that the position of the testimony of the verbal witnesses referred to can be assessed as a condition that is compatible with the evidence of the defendant's testimony.

In contrast, if it is reviewed from Article 188 Paragraph (2) of the KUHAP, which determines that guidance can only be obtained from witness testimony, letters, and statements of the defendant, it can be juridically analyzed that the testimony of a verbal witness so that it can be valuable as an indication is very dependent on its relevance to the evidence in question. Furthermore, if we pay close attention to Article 188 Paragraph (3) of the KUHAP, which determines that the power of proof of an indication is carried out by a judge wisely and wisely after he has conducted an examination with full accuracy and thoroughness based on his conscience. So it can be analyzed that the placement of the verbal witnesses' testimony as an indication returns to the authority of the judge so that the judge has the freedom to determine whether or not the testimony of the verbal witnesses is used as a means of evidence to make a decision.

\section{b. With the expansion of the understanding of witnesses in the Constitutional Court decision Number 65/PUU-VIII/2010.}

Furthermore, about the placement of verbal witness testimony as evidence for witness testimony, with the expansion of the understanding of witnesses in the Constitutional Court decision Number 65/PUU-VIII/2010, it can be analyzed that it is highly irrelevant if the testimony of a verbal witness is considered the same as evidence for a witness's testimony. Because, juridically a verbal witness is an investigator who initially investigated the accused so that the information given at trial is, of course, not information that has a direct relationship with the criminal case concerned but is limited to administrative procedures regarding the conduct of examinations at the investigation level, in other words. The testimony of the verbal witnesses cannot be used as a basis for examining the occurrence of a criminal act as contained in the indictment of the public prosecutor, and it is the defendant who is guilty of committing it.

Based on the 2 (two) points of view referred to, the testimony of verbal witnesses is more relevant to be placed as evidence in Article 188 of the KUHAP if it is placed as evidence for witness testimony in Article 184 Paragraph (1) letter a of the KUHAP. Although the KUHAP does not provide clear regulations regarding the use of verbal witness testimony as a means of evidence in proving a criminal case at trial, the position of verbal witness testimony cannot be separated from the objective of implementing the criminal justice system itself.

When correlated with the theory of the criminal justice system (open system) as put forward by J.W. Lapatra, which describes the interaction of the criminal justice system with its environment, which consists of rank (level) 1: society, rank (level) 2: economy,

\footnotetext{
${ }^{19}$ Interview with the Central Lampung District Attorney's Office on May 5, 2020.
} 
technology, education and politics, and rank (level) 3: subsystem of criminal justice system. ${ }^{20}$ It can be analyzed that the position of verbal witnesses in proving criminal cases at trial is influenced by the subsystem of criminal justice system factors, in this case, it is related to the legal interests of proving criminal cases in court by law enforcement officials, namely public prosecutors who are ranked 3rd (three) according to J.W. Lapatra's theory. Proof of a criminal case is carried out through a trial mechanism based on the procedures stipulated in the KUHAP, so the objective to be achieved for the use of verbal witnesses is to find the material truth of a criminal incident submitted to the judge through the indictment as well as to prove the defendant's guilt for committing a criminal act. Based on relevant evidence so that it can be sentenced to be convicted by a judge.

Based on the description, juridically, the testimony of verbal witnesses is very relevant to be placed as evidence of evidence because the essence of the position of verbal witnesses is to explain facts, events, circumstances that are compatible with the criminal act as contained in the indictment of the public prosecutor. This is because the proof is also a provision that regulates evidence that is justified by law, and it is permissible for the judge to prove the guilt charged by the public prosecutor.

\section{Strength of Verbal Witnesses Statement's Verification in a Criminal Case}

The trial stage has a vital position because there is a procedure of proof according to the law carried out by the judge to determine whether the accused is guilty and can be held accountable for the actions that the public prosecutor has accused him of because the judge's decision is obliged based on facts and circumstances as well as the means of evidence obtained from the results of the examination at court proceedings. ${ }^{21}$ The problem with the position of verbal witnesses that is commonly used as a means of proof in judicial practice has yet to have a clear legal basis, either in the KUHAP or in its implementing regulations, this should require attention from the Supreme Court and the government to immediately provide a legal basis in the form of a Supreme Court Regulation or the form of a Government Regulation so that the position of verbal witnesses will no longer lead to various interpretations among legal practitioners and legal academics.

Seeing the essence of a verbal witness is an investigator who initially examines witnesses and suspects. His presence in court is only limited to providing information related to technical matters or the investigation process. The judge will use this statement to assess the reasons for the withdrawal of the information from the Investigative BAP by the defendant, which functions as the provision of information or additional knowledge for the judge about the occurrence of a criminal event as described in the indictment of the public prosecutor and to give the judge confidence in his verdict. This is one of the juridical reasons that the testimony of verbal witnesses in the practice of criminal proceedings is used as an indication. For this matter, the determination of the strength of the evidence is based on the requirements as stipulated in Article 188 Paragraph (1) and Paragraph (2). However, the only one who has the authority to use the testimony of a verbal witness as evidence is the judge. This is based on the provisions of Article 188 Paragraph (3) of KUHAP.

From the aspect of usefulness, the verbalized witness's testimony was intended as a crosscheck of the defendant's denial of the information that was previously given during the investigation stage and was posted on the suspect's investigation report. ${ }^{22}$ Furthermore, when viewed from the aspect of legal certainty, the cross-check is intended to make clear a criminal

\footnotetext{
${ }^{20}$ Kadri Husin, Buku Ajar Sistem Peradilan Pidana (Bandar Lampung: Bagian Hukum Pidana Fakultas Hukum Universitas Lampung, 2011): 9.

${ }_{21}$ Maroni Maroni, Wajah Hak Asasi Manusia Dalam Peradilan Pidana (Bandar Lampung: Aura Publishing, 2018): 214.

${ }^{22}$ Interview with the Central Lampung District Attorney's Office on May 5, 2020.
} 
event to not cause mistakes for the judge in deciding on the criminal case he is currently trying. Thus, although the use of verbal witness testimony is not regulated in the Criminal Procedure Code, the judicial practice has provided flexibility and opportunity for public prosecutors as parties who have a burden of proof in criminal cases to make evidentiary efforts using evidence outside the provisions of Article 184 Paragraph (1) KUHAP. The judge gives the freedom to the public prosecutor to present verbal witnesses shows that the judge's actions are not only tied to the formal procedure of the proof system negatively based on the law, which is based on the fulfillment or use of evidence as regulated in Article 184 Paragraph (1) of the KUHAP, this matter shows the progressive judge's attitude in responding to the revocation of the BAP statement by the defendant. ${ }^{23}$

In connection with the withdrawal of the BAP by the defendant, the judge could not act rashly and simply believe in the reasons put forward by the defendant but required concrete facts by ordering the prosecutor to present the investigator to be a verbal witness at the trial. Likewise, vice versa, when the judge listens to the testimony of the verbal witnesses, the action he takes is complying with other evidence and the facts of the trial that have been revealed to test the testimony given by the verbal witnesses. This is done to find a clue as an act, event, or situation related to a criminal event as contained in the indictment of the public prosecutor. The evidentiary strength of the evidence of guidance is based on the judge's observation to assess the conformity between the existing facts and the criminal act accused and the correspondence between each evidence and the facts and the criminal act charged. From the existence of the word conformity, it can be concluded that there must be at least two clues to obtain valid evidence. This evidence's strength lies in the number of acts that are considered indications of the actions that the defendant is accused of.

The assessment or strength of evidence of verbal witness testimony as evidence of guidance is based on the existence of the testimony of the verbal witness itself, which is situational, that is, if the judge or public prosecutor requires verbal witness testimony, the investigator concerned should be presented, and vice versa if the judge does not need it, the investigator referred to will not be presented. This confirms that the testimony of verbal witnesses is not a primary means of evidence so that its existence does not have the most decisive character on the results of evidence of a criminal act that is being examined at trial but only functions as a provider of information or additional knowledge for judges about the truth of a criminal incident as described in the indictment of the public prosecutor and its relevance to the reasons for the withdrawal of the statement of the investigation report conducted by the defendant to provide confidence in the judge in making a decision.

This research's evidentiary theory is the negative (negatief wettelijk) statutory proof theory, which requires 2 (two) things to be fulfilled. ${ }^{24}$ First, proof must be carried out utilizing evidence that is valid according to law. Second, the judge's conviction must be based on valid evidence according to law. This system combines "objective and subjective" elements in determining whether the defendant is guilty or not. Nothing is the more dominant of the two elements. If one of the two elements is missing, it is not sufficient to prove the defendant's guilt. ${ }^{25}$ In criminal law, there is also a term where one piece of evidence is not evidence (unus testis nullus testis).

This theory's relevance to this study is to analyze the strength of evidence of verbal witness testimony as evidence concerning the judgment for the accused. Regarding this

\footnotetext{
${ }^{23}$ Brian Siahaan, "Kajian Yuridis Tentang Saksi Pengungkap Fakta (Whistleblower)," Lex Crimen 4, no. 1 (February 13, 2015): 178-87, https://ejournal.unsrat.ac.id/index.php/lexcrimen/article/view/7013.

${ }^{24}$ Yusnita Yusnita, Muhammad Syarief Nuh, and Satrih Hasyim, "Efektivitas Pelaksanaan Pembuktian Terbalik Dalam Perkara Tindak Pidana Korupsi," Journal of Lex Generalis (JLG) 1, no. 7 (December 31, 2020): 102443, http://pasca-umi.ac.id/index.php/jlg/article/view/284.

${ }^{25}$ M. Yahya Harahap, Pembahasan Permasalahan Dan Penerapan KUHAP: Pemeriksaan Sidang Pengadilan, Banding, Kasasi Dan Peninjauan Kembali (Jakarta: Sinar Grafika, 2001): 258.
} 
matter, so that the testimony of a verbal witness can be used as the basis for a judge's judgment, it must have evidentiary value and be able to assure the judge as regulated in Article 188 Paragraph (1) and Paragraph (2) of the KUHAP, among others as follows:

a. The statement conveyed by the verbal witness before the trial must contain the substance of the actions, events, or circumstances of the defendant at the time the investigator is being examined at the stage of investigation and must be in conformity with the criminal acts that the public prosecutor is charged with. The elements mentioned above are related to the main reason for the presence or use of the verbal witnesses' testimony at the trial, which is to assess the reasons for the withdrawal of the information contained in the investigation report by the accused. ${ }^{26}$ Suppose the testimony of the verbalized witness is obtained because the revocation of the BAP statement submitted by the defendant is correct. In that case, the verbal witnesses' testimony can serve as a guide for the judge to give an acquittal for the defendant. In contrast, if based on the verbal witnesses' testimony, the fact is that the reasons for the withdrawal of the testimony are obtained. The BAP by the defendant is incorrect, so it can be used as a guide for the judge to judge the defendant's wrongdoing for the crime described by the public prosecutor with the indictment.

b. The substance of the testimony of a verbal witness must be following other evidence, namely the testimony of witnesses, letters, and statements of the accused. The results of the testimony of the verbal witnesses are not binding for the judge and do not have absolute evidentiary power but must be supported by a cumulative statement of witnesses, letters, and statements of the accused. For the testimony of the verbal witnesses that have conformity with the other means of evidence referred to, the judge will place them as evidence of evidence because they have the power of proof to be used as evidence to decide following the theory of negatief wettelijk. Based on this, a witness's position in every trial of a criminal case is critical because witness testimony can influence and determine the tendency of a judge's decision.

\section{Conclusion}

The expansion of witnesses understanding in the Criminal Procedure Code or Kitab UndangUndang Hukum Acara Pidana (KUHAP) after the Constitutional Court decision Number 65/PUU-VIII/2010 has implications for the emergence of an interpretation that verbal witnesses can be placed as a means of evidence in criminal cases. However, if you look at the nature of the testimony of a verbal witness that is not primary evidence or is not directly related to a criminal case that is being examined at trial because its existence is situational, that is, it depends on the judge's will to use it, then the broadening of the meaning of the witness does not automatically place verbal witnesses are included in the group of evidence for witness testimony in Article 184 Paragraph (1) letter a of the KUHAP, but it is more relevant to be placed in the group of indicative evidence as stipulated in Article 184 Paragraph (1) letter d of the KUHAP. Jo. Article 188 of the KUHAP. The strength of verbal witness statement' verification must meet 2 (two) requirements. First, it is based on Article 188 Paragraph (1), which is that the statement conveyed by a verbal witness before the trial must contain the substance of the actions, events, or circumstances of the defendant at the time the investigator is being examined in the investigation stage and has conformity with the criminal act the public prosecutor is accused of the defendant. Second, it is based on Article 188 paragraph (1), which states that the substance of the verbal witness' testimony must be consistent with other evidence.

${ }^{26}$ Yusuf Yusuf, "Akibat Hukum Terhadap Keterangan Saksi Yang Dicabut Di Depan Persidangan," Dinamika: Jurnal Ilmiah Ilmu Hukum 25, no. 1 (January 30, 2019): 1-13, http://www.riset.unisma.ac.id/index.php/jdh/article/view/1976. 


\section{Bibliography}

\section{A. Books}

Harahap, M. Yahya. Pembahasan Permasalahan Dan Penerapan KUHAP: Pemeriksaan Sidang Pengadilan, Banding, Kasasi Dan Peninjauan Kembali. Jakarta: Sinar Grafika, 2001.

Hiraiej, Eddy O.S. Teori Dan Hukum Pembuktian. Jakarta: Erlangga, 2012.

Husin, Kadri. Buku Ajar Sistem Peradilan Pidana. Bandar Lampung: Bagian Hukum Pidana Fakultas Hukum Universitas Lampung, 2011.

Maroni, Maroni. Wajah Hak Asasi Manusia Dalam Peradilan Pidana. Bandar Lampung: Aura Publishing, 2018.

\section{B. Journals}

Amin, Muhammad Erham, and Putri Damayanti. "Kekuatan Pembuktian Penyidik Kepolisian Selaku Saksi Dalam Persidangan Tindak Pidana Narkotika." Badamai Law Journal 4, no. 2 (September 25, 2019): 256. https://doi.org/10.32801/damai.v4i2.9236.

Andriyanto, Andriyanto. "Pencabutan BAP Oleh Terdakwa Di Muka Persidangan Dalam Sistem Peradilan Pidana." LEX CRIMEN 7, no. 2 (May 22, 2018): 105-12. https://ejournal.unsrat.ac.id/index.php/lexcrimen/article/view/19600.

Aryaputra, Muhammad Iftar, Dharu Triasih, Endah Pujiastuti, Ester Romauli Panggabean, and Reny Puspita Dewi. "Peranan Keterangan Saksi Sebagai Salah Satu Alat Bukti Dalam Proses Pidana Menurut KUHAP." Jurnal Dinamika Sosial Budaya 20, no. 2 (January 21, 2019): 91. https://doi.org/10.26623/jdsb.v20i2.1241.

Bierschbach, Richard A., and Stephanos. Bibas. "Rationing Criminal Justice." Michigan Law Review 116, no. 2 (2017): 187. https://repository.law.umich.edu/mlr/vol116/iss2/1.

Campbell, Bradley A., Tasha A. Menaker, and William R. King. "The Determination of Victim Credibility by Adult and Juvenile Sexual Assault Investigators." Journal of Criminal Justice 43, no. 1 (2015): 29-39. https://doi.org/10.1016/j.jcrimjus.2014.12.001.

Elvandari, Henny, Burham Pranawa, and Joko Mardiyanto. "Kedudukan Saksi Verbalisan Dalam Proses Pemeriksaan Di Persidangan." Jurnal Bedah Hukum 4, no. 2 (October 31, 2020): 10-19. https://www.ejournal.uby.ac.id/index.php/jbh/article/view/451.

Erna Dewi. "Rekonstruksi Budaya Hakim Pada Penegakan Hukum Pidana Dalam Konteks Siskumnas/Bangkumnas.” Jurnal Kompilasi 1 (October 28, 2014): 106378. https://www.neliti.com/id/publications/106378/.

Hoyano, Laura. "Reforming the Adversarial Trial for Vulnerable Witnesses and Defendants." Criminal Law Review 2, no. February 2015 (2015): 107-29.

Kawengian, Tiovany A. "Peranan Keterangan Saksi Sebagai Salah Satu Alat Bukti Dalam Proses Pidana Menurut KUHAP.” Lex Privatum 4, no. 4 (April 27, 2016): 30-37. https://ejournal.unsrat.ac.id/index.php/lexprivatum/article/view/11990.

Kostenko, Roman V., and Artem Rudin. "Notion And Meaning Of Evidence Verification In Criminal Procedure." Journal of Advanced Research in Law and Economics 9, no. 3 (2018): 1011.

Krisnamurti, Hana. "Kedudukan Saksi Anak Dalam Pembuktian Perkara Pidana." Wacana Paramarta: Jurnal Ilmu Hukum 15, no. 2 (2016): 1-11. http://paramarta.web.id/index.php/paramarta/article/view/28.

Morisson, Joanne, Jill Bradshaw, and Glynis Murphy. "Reported Communication Challenges for Adult Witnesses with Intellectual Disabilities Giving Evidence in Court." The International Journal of Evidence \& Proof 25, no. 4 (2021): 243-63. https://doi.org/10.1177/13657127211031040.

Rusyadi, I. "Kekuatan Alat Bukti Dalam Persidangan Perkara Pidana." Jurnal Hukum 
$\begin{array}{llllll}\text { PRIORIS } & 5, \quad \text { no. } & 2 & \text { (February } & 13, & 2016):\end{array}$ https://trijurnal.lemlit.trisakti.ac.id/prioris/article/view/558.

Salut Murniasih. "Pembuktian Berdasar Keterangan Saksi Verbalisan Akibat Pencabutan Keterangan Terdakwa Di Persidangan Dalam Perkara Persetubuhan Terhadap Anak." $\begin{array}{llllll}\text { Jurnal Verstek } & 7, & \text { no. } & 2 & \text { (2019): }\end{array}$ https://jurnal.uns.ac.id/verstek/article/view/34306.

Siahaan, Brian. "Kajian Yuridis Tentang Saksi Pengungkap Fakta (Whistleblower)." Lex Crimen 4, no. 1 (February 13, 2015): 178-87. https://ejournal.unsrat.ac.id/index.php/lexcrimen/article/view/7013.

Yusaf A., Ganda. "Kewajiban Menyampaikan Surat Dakwaan Oleh Penuntut Umum Kepada Terdakwa Atau Penasihat Hukumnya." Jurist-Diction 2, no. 3 (July 11, 2019): 891. https://doi.org/10.20473/jd.v2i3.14361.

Yusnita, Yusnita, Muhammad Syarief Nuh, and Satrih Hasyim. "Efektivitas Pelaksanaan Pembuktian Terbalik Dalam Perkara Tindak Pidana Korupsi." Journal of Lex Generalis (JLG) 1, no. 7 (December 31, 2020): 1024-43. http://pascaumi.ac.id/index.php/jlg/article/view/284.

Yusuf, Yusuf. "Akibat Hukum Terhadap Keterangan Saksi Yang Dicabut Di Depan Persidangan.” Dinamika: Jurnal Ilmiah Ilmu Hukum 25, no. 1 (January 30, 2019): 1-13. http://www.riset.unisma.ac.id/index.php/jdh/article/view/1976.

\section{Regulation}

Constitutional Court's Decision No. 65/PUU-VIII/2010.

Law No. 8/1981 on the Law of Criminal Procedure. 
